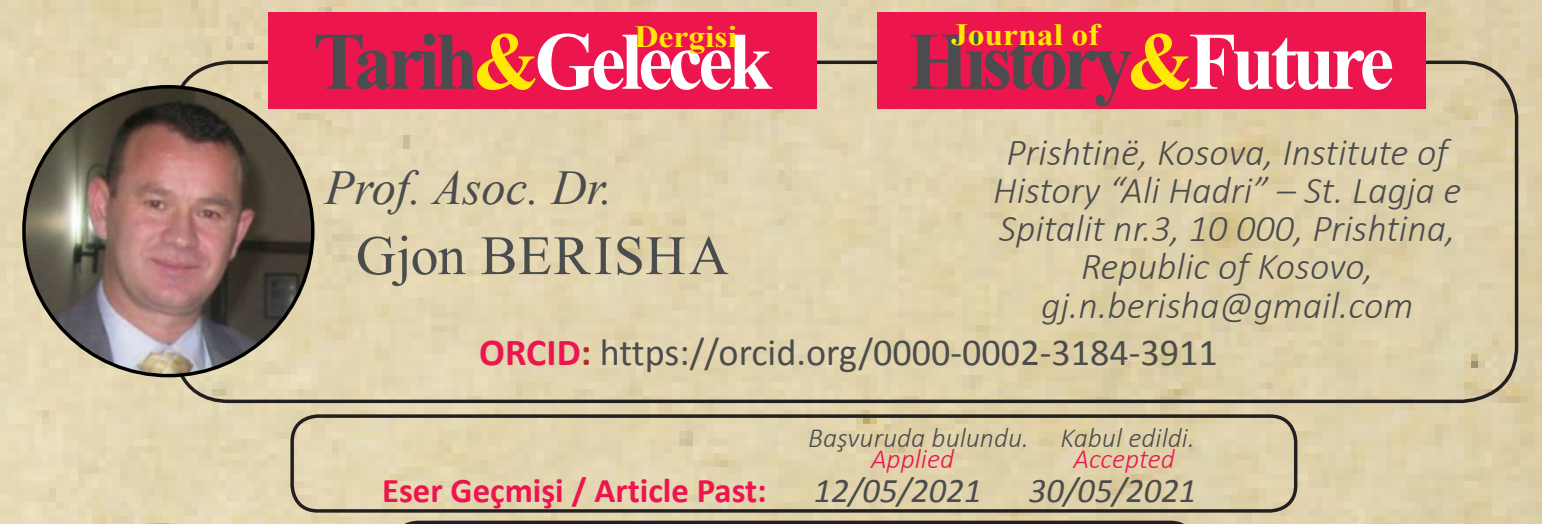

Araştırma Makalesi

DOI: http://dx.doi.org/10.21551/jhf.936658

Research Paper

Indexed by

ERIHPDINS

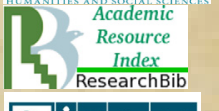

QISAM
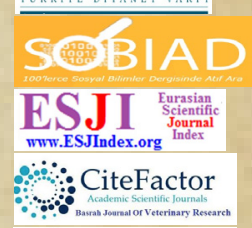

ideal

Orjinal Makale / Orginal Paper

\title{
Albanians in the Ragusan Sources during the Middle Ages
}

\section{Dubrovnik Devlet Arşivinde Bulunan Ortaçă̆ Arnavutlarına İlişkin Kaynak Belgeler}

\section{Abstract}

The historical circumstances we have experienced as a nation under the rule and occupation of the great empires or religious administration of the Vatican, Byzantium and Istanbul, and under the cultural influence of languages: Greek, Latin, Turkish, and Slavic, all together, created many voids or emptiness concerning important periods of our national history. The written sources were mainly preserved outside Albania, in different states, in many archives, in public, private or church libraries, and mostly in foreign languages. One of the richest Middle Age archives (especially for the XII-XV century) concerning the history of Albanians in particular and of the Western Balkan in general, is the State Archive in Dubrovnik, ${ }^{1}$ due to the important role that Dubrovnik had in economic, social and financial relations with neighbouring countries. The funds of this archive contain numerous documents, acts and testaments, of a public or private character, about Albanians and territories they lived. Most of them were written in Latin, Italian, Slavic and the Ottoman language.

Key words: State Archive in Dubrovnik, SAD, archive, Albanians, archive funds, documents, Kosovo, Skanderbeg

\section{$\ddot{\mathbf{O} z}$}

Arnavut Milleti tarihte Batı Roma, Doğu Roma (Bizans) ve Osmanlı İmparatorluğununişgali ve hâkimiyeti altında kalmış olup, kültür ve dil bakımından Yunan, Latin, Türk/Osmanlı ve Slavların etkisi altında kendini bulmuştur. Bu tarihlerin Arnavutlar açısından önemli dönemleri kapsaması

1 Since the year 1920, as an independent institution, this archive (SAD/DAD) several times changed his name: Dubrovački arkiv(1920-1950), Državni arhiv u Dubrovniku (1950-1967), Historijski arhiv u Dubrovniku (1967-1990), Povijesni arhiv u Dubrovniku (1990-1997), Državni arhiv u Dubrovniku (1997 - continues with the same name). 
nedeniyle bu durum, bahsedilen alanlarda bir takım boşluklar meydana gelmesine sebep teşkil etmiştir. Bu dönemlerle ilgili arşiv kayıtları,söz konusu dillerde genellikle Arnavutluk dışındaki devlet arşivlerinde, kiliselerde, değişik büyük kütüphanelerde ve kişisel olarak arşiv kaydı yapan kimselerin kütüphanelerinde yer almaktadır. Ortaçağ dönemi içerisinde ve özellikle XII-XV. yüzyıllara ait arşiv kayıtları açısından Dubrovnik Devlet Arşivi en önde gelen kayıtlardan biri olup, Arnavutluk ve Balkan tarihine 1şı tutan en önemli belgeler içerisinde yer almaktadır. Dubrovnik arşiv kayıtlarının bu denli önem arz etmesinin en önde gelensebeplerinden biri, Dubrovnik'in Balkan bölgeleri ile olan kültürel, ticari, ekonomik ve sosyal ilişkileridir. Ayrıca bu kayıtlarda Arnavutlar ve Arnavutluk tarihi açısından özel ve kamu ilişkilerinin yanı sıra değişik alanlarla ilgili farklı belgeler bulunmaktadır. Bu belgelerin genellikle Latince, İtalyanca, Slavca ve Osmanlıca dillerinde yazılmış olduğu bilinmektedir.

Anahtar kelimeler: Dubrovnik Devlet Arşivinde, Archive, Arnavut, Arnavutluk, Kosova, arşiv fonları, belgeler, Ortaçağ, Skanderbeg

\section{Introduction (History and development)}

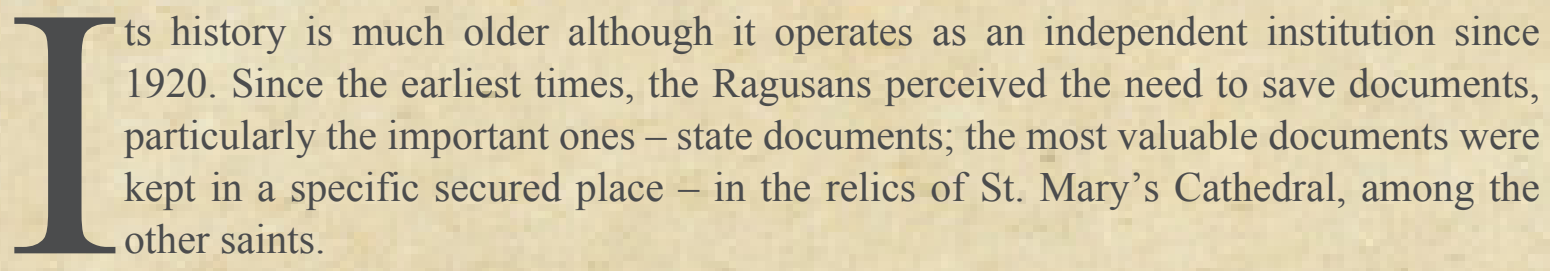

Since the early days of its existence as a medieval city, municipality, then as a republic, and as an independent state - Dubrovnik has paid particular attention to the written word and the cautious preservation of documents. It is known that valuable documents were kept (secured) in the most sacred place-in the city's cathedral, along with the relics of the saints. The love and concern about the old documents provided the opportunity to Dubrovnik to dispose numerous documents dated since the beginning of XI century up to present.

Archival materials from the State Archive of Ragusa (SAD) are of great cultural and national significance and for Albanians, and an inexhaustible source of cultural and historical heritage. It is one of the most important archives in Europe because of the amount of material kept there, its age and value. The care of documents created during the Republic of Ragusa has been long and rich. National Archives in Dubrovnik is one of the rare archives where archival materials, created over many centuries, were successfully preserved because of timely rebinding and repairs to damaged materials, as well as the high-quality material used to make them.

From the very beginning of the written word in the Republic of Ragusa, a lot of attention was devoted to the preservation of documents. People of Dubrovnik kept charters and contracts safe to ensure the legal security of the Republic and its citizens. Contracts were drawn up that testify to friendship and freedom, including numerous charters on peace and trade with rulers from the Balkan hinterland, especially with Albanians. Sales contracts, receipts on money lending, - marriage agreements, last wills and testaments of Dubrovnik nobility and common people - in short, everything that made up the everyday life of the people of Balkan can also be found there. 
According to the well-known archivist, Gregor Cremošnik, the Dubrovnik municipal authorities, due to the increasingly commercial (trading) and cultural activities, which had to be kept in the written form, decided to set up in the year 1277 or 1278 a municipal notary office, which was considered as the year of the establishment of the archive. In the same year appeared Tomasino de Savere from Reggia of Lombardy, as the first educated notary, who was paid by the state - a secular who begun to manage the notary office and official books. ${ }^{2}$ Since then until the fall of Dubrovnik republic in 1808, and later, the office was supplied with first hand sources, increasing the quality and quantity of materials, listing it among the richest current archives. In order to conduct an easier registration Tomasino arranged documents in respective series and made separate volumes or books for each of them. At the beginning of 1284 the State Office was divided into Chancellery (Judicial and State Affairs) and Notary Office (written regulation of private legal affairs). ${ }^{3}$

The Serbian aggression against the Republic of Croatia in 1991 did not spare either the old town of Dubrovnik or the Palace of Sponza, where the archive was located. According to today's archive staff, preventive measures to protect archive treasures resulted in the microfilming of material and its relocation to Italy. After the war all the collections returned back to their original place.

If we talk in archival terms, this archive owns: more than 400 funds and collections, over 100,000 independent documents from the Fund of the Republic of Dubrovnik, over eight kilometers of material, over 7,000 binding funds (books), manuscripts and printed books of scholars and writers as well as collections of old geographic maps, pictures, etc.

It should be noted that the archival funds in SAD, are characterized between the quantity and the quality of the documents, the second one being always on the lead.

\section{Early documents about Albanian language and Albanians}

As a medieval state, whose general development was not grounded on the war, but on the trading activities, during the XII and XIII centuries, Dubrovnik had concluded several treaties of friendship and free trade with communes, rulers, nobles and similar cities in the Adriatic and Mediterranean. Amongst them there was a trade treaty between the prince of Arbanon, Dhimitri, and Ragusa, concluded in $1210 .{ }^{4}$ In fact, this is the single document we have concerning the activities of the Arbanon Principality. The document was written in Latin, it is quite damaged and was drafted in accordance to needs of Arbanon Principality in attempts for friendship and agreement with neighbors in order to prevent the threat coming from Venice. According to this document the Prince of Arbanon, Dhimitri, confirmed the free movement for Dubrovnik traders along Arbanon, being excluded from taxes.

2 Gregor Čremošnik, “ Kada je postao Dubrovački arhiv?”, Glasnik Zemaljskog muzeja 44 (Sarajevo, 1932), pp.57-58

3 Josip Gelčić, "Dubrovački arhiv (Catalogus i.r.Archivii ragusani)", Glasnik Zemaljskog muzeja 22 (Sarajevo, 1910, pp.545-589; Vinko Foretić, "Dubrovački arhiv u srednjem vijeku", Anali Historijskog instituta JAZU u Dubrovniku, 6-7 (Dubrovnik, 1959), pp.315-336. 
When we talk about the use of these materials for the Albanian medieval history, it should be noted that the oldest original document kept in this archive, which bears the date 22 September 1022, has to do with Albanians lands. It is a plea of Pope Benedict the VIII addressed to Vitali - the Archbishop of Ragusa, informing that Kotorr, Tivar (Bar) and Ulcinj joined to this archbishopric, expanding thus territories and influence of Latin churches. ${ }^{5}$ Additionally, the oldest document concerning the Albanian language was again linked to the funds of these archives. This document, when for the first time was mentioned the Albanian language, is still located in SAD, it bears the date 14 July 1284 and says: "Audivi unam vocem clamantem in monte in lingua albanesca" - "I heard a voice in the forest in the Albanian language". 6

The funds of this archive contains one of the oldest versions of the Albanian name derived from a family from Drishti (Schibudar, Schapudar...) which emerges from a document issued in Ragusa on 4 August $1402 .^{7}$

In the Archives of Dubrovnik, in the original documents for the XIV century, who are stored in the fund: Series of Vienna documents, signature No. 1019, there is an original document bearing date 2 September 1368, where for the first time in history (from the known documents up to day) the name Kastriot was mentioned. The document was written in Old Slavonic - Cyrillic graphs with Glagolitic elements. ${ }^{8}$

We said above that the Albanians appear in the Ragusa sources from the beginning of the preservation of documents in this city, and by the end of the XIII century Albanian cities as Vlora and Durres were mentioned in city's statute of 1272 . The archival sources indicate that a considerable number of Albanians, who lived or stayed in Ragusa, were engaged in different occupations or as visitor traders, trade mediator, clerics, etc. There were cases where Albanians in Dubrovnik and surrounding area, were involved in cases of violence, lootings, conflicts and attacks.

The notary acts of the XIV century indicated numerous cases when the Ragusa ships and sailors were employed by the Venetians to travel to Vlora, Spinarca and other places in Albania.

Of particular interest are the records of the Albanian Catholic clergy, who were in number in Ragusa and who had managed to achieve high church ranks, and who in addition to the duty of a priest, were found as a notary or witnesses on different occasions. What is most important in this case, it should be noted that part of this clergy was bearing the last name "Albanenses". 9

Based on the documents of this archive, it turns out that Albanians were not only known as tradesmen and craftsmen, but among them there were also scholars who became very successful and also prominent in Dubrovnik. According to the local Ragusa tradition, in 1380 the noble family Spani moved from Shkodra to Dubrovnik and one of its members, "Magister Georgius Spanus, Medicus", in 1444, after completing his education in Paris, worked at the doctor's office in Ragusa, where he received a high salary of 500 hyperpera, and in 1449 got a further allowance of 100 hyperpera Spani had not only cured residents in Dubrovnik, but also prominent personalities in

5 SAD, Diplomata et acta XI i XII. st., PP. 1.

6 SAD, Diversa cancellariae 1284-1286, vol. 2, fl. 111r.

7 SAD, Diversa notarie, 1402-1408, vol.11, fl.24v.

8 SAD, Acta Sanctae Mariae Maioris, seac XIV, fac.I, no.116.

9 Teuta Shala, "Prania e etnonimit Albanensis në Raguzë gjatë mesjetës, sipas burimeve dokumentare", Kosova 41 (Prishtina, 2016), pp. 45-51. 
Herzegovina and Montenegro.

\section{Gazulles and the other}

However, the Gazulli was the most prominent Albanian family during the XV century in Dubrovnik (they also appear as Gazulus, Gasolo, Gasola, Gaxulus, etc.), whose roots goes to northern Albanian; "Don Matcus / Mateus Gaxuli, dictus parvus / pizolo", was the first mentioned amongst the members of this family in the documents of Ragusa. Then, there are two of his grandsons, Gjin and Gjon Gazulli. ${ }^{10}$ The last one was undoubtedly most well-known and one of the most famous of Albanian origin of all times in Ragusa. ${ }^{11}$ As a scholar, astronomer, diplomat and ecclesiastic he played an important role in Ragusa's international affairs as well as in domestic development, particularly in the intellectual history of this city. When he died on 19 February 1465 he left a testament, and amongst his inheritance was a large collection of books that he put into service to readers; this collection served as a ground for establishment of the first scientific library in Dubrovnik, which is active even today.

The SAD funds and collections contain some original documents about our national hero, Gjergj Kastrioti Skanderbeg. ${ }^{12}$

It should be emphasized that Ragusa maintained a continuous and positive relationship with Skanderbeg. This relation goes back to the age of Skanderbeg's father, Gjon Kastrioti, to whom in early 1413 were granted some trade privileges and the citizenship of Ragusa. Those benefits were transferred even to his sons in 1439.

Particularly, numerous documents concerning Skanderbeg are kept in different funds of SAD: Acta Sanctae Maria Maioris, Diplomata et acta of century XV and in a fund named as the Fund of Vienna.

Gjon Gazulli is known as a mediator between Skanderbeg and Ragusa; he was successful in his efforts: in April 1451 Pope Nikola V released an order - the collected indulgences in Ragusa's territories had to be divided between Ragusa and Skanderbeg. ${ }^{13}$

\section{Trade and mining}

There are numerous documents concerning Kosovo, and about the trade, ethnic, religious and social circumstances. Amongst other, during the century XV there was a hospital within the Cathedral of St. Nicholas in Novoberde/Novo Brde. ${ }^{14}$ The book of a Ragusan merchant Mikel Lukari, third decade of century XV, which deals exclusively with Novobede/Novo Brdo and its surrounding, provides plenty of information regarding the economic and ethnic conditions in

10 SAD, Distributiones testamentorum, vol. 8, 1419-1427, fl. 66v, 218v.

11 Šime Jurić, "Prilozi Biografiji Ivana Gazulića", Anali Historiskog instituta Dubrovnik, God. VIII-X (Dubrovnik, 1962), pp.447-479; Drançolli, 1984.

12 Gjon Berisha, Gjergj Kastrioti-Skënderbeu në fondet e Arkivit Shtetëror të Dubrovnikut: dokumente, Prishtinë: Instituti i Historisë“Ali Hadri”, 2018, passim.

13 SAD, Acta Sancte Mariae Maioris, seac.XV, fasc.I, no.31.

14 SAD, Testamenta notariae, vol.XI, fl.126v-127; 236r. 
Kosovo $^{15}$ during the medieval period.

There are also a lot of documents released by Serbian kings regarding Kosovo ${ }^{16}$ and northern Albanian regions.

If we take into account the rich documentary sources of SAD regarding the past of present territory of Kosovo until 1455, by other words until the Turkish conquest of the most of it, and when we are aware about the lack of medieval diplomatic sources about the history of these lands, excluding the Serbian documentary sources, and if we consider the advantages of diplomatic sources over narrative ones, we may reach the conclusion that it is not possible to draft the medieval history of Kosovo without using the documentary sources stores in this archive. By other words, the Dubrovnik State Archive is the single archive in the region and in the world that has the most direct and indirect source information for the reconstruction of Kosovo's historical past of the Middle Age.

The information source (documentation) that is stored in SAD imposes the need for the collection, preservation, selection and decoding and their publication in form of special summaries. This task should be exercised even by national libraries, which are entitled to enrich the country's memory funds.

The interest in the archival funds found in SAD is understandable due to the economic and cultural ties that the Arbanon areas of medieval Kosovo had with the commercial Republic of Dubrovnik.

In regards to present territory of Albania, the Republic of Dubrovnik did not have possessions in Albania and consequently its archives do not provide as much data of a political nature, as it is the case with the materials of the Venice archive. However, this does not mean that the funds of this archive are second-handed and politically insignificant. On the contrary, in certain periods and stages it is even the materials of this archive that take precedence over all other archives not only in economic-commercial, but also political terms. This can be particularly claimed for the second half of century XIV, when the Arbanon feudal principalities were transformed into important economic and political factors in the Arbanon and Balkan scale.

Ragusa's old economic and trade interests and connections in the Balkans brought her in direct contact with the Arbanon territories and society. Through the information received from its traders, Dubrovnik was always well and closely informed about the economic aspects and political events in the Albanian territories.

One of the Arbanon families, which is extremely present in the funds of the SAD archive is the family and the Principality of Balshaj, which extended to the most important lines of trade of Dubrovnik goods in the territory of Kosovo and low coastal areas of Albania. In addition to the mutual relations between Balshaj and Dubrovnik, the former for a certain period also owned Dubrovnik itself, which is proved through a large number of documents. These materials of the Dubrovnik archive, deriving from the funds "Lettere et comissioni di Levante" and "Reformationes", provide interesting data, particularly about the political history of Balsha Principality, its struggle against Kotor and Republic of Venice, and about the stance of Ragusa towards Balshaj's in events

15 Mihailo Dinić, Iz dubrovačkog arhiva, I, Beograd: SANU, 1957, passim.

16 SAD, Diversa Cancellariae, vol.XV, fl.27r. 
mentioned above.

Although often sporadic and fragmentary, the overall material pertaining to economic ties between two countries includes the political documents as well. The materials of the Dubrovnik archive acquire a special and first-hand value in political terms, as a result of the important events that took place in the Arbanon territories starting from the years ' 30 of century XV when the Ottoman rule was established in the territory mentioned above. Officials and people of Dubrovnik, who closely followed the events, reported to the Republic of Dubrovnik, while the latter informed Sigizmund, King of Hungary - the most interested country in the war against the Ottoman Turks. ${ }^{17}$ Here we have important sources and information about the wave of anti-Ottoman uprisings that pervaded Arbanon during these centuries.

The organized anti-Ottoman war that took place in the second half of the century XV under the leadership of our national hero Gjergj Kastriot Skanderbeg, for its role in defense of European civilization, attracted the attention of the most important states of the time, who were interested in defense against the Ottoman threat. In addition to other archives rich in materials, such as Naples, Barcelona, Milan, Rome, Venice, etc., the archives of Ragusa are listed as the most important to shed light on the glorious period of our medieval history and that of European in general. But, what draws attention of the researchers to the archive of Ragusa, in the first instance, is the wealth of stored data regarding the trade activities conducted by merchants of these republics in other parts of the world including Arbanon regions as well, as the most important courses of their trade. This particularly emphasized in Kosovo, where people from Dubrovnik had their own colonies. ${ }^{18}$

In order to shed some light over the issue of Ragusans in Kosovo, from the vast majority of SAD documents, the decisions of Minor Council of Dubrovnik, known as Acta Consilii Minoris, which mainly presented court disputes, are of a great value. In this series of documents, which starts in 1415, the cities of Kosovo, as Trepça, Novobërda, Prizren, Prishtina and Janjeva, were mentioned in almost every third or fourth document. ${ }^{19}$

Besides to the data that shed light on the economic and political development of the country, these archives, especially those of Ragusa, preserve materials of irreplaceable value about the presence of the Albanian element in Ragusa, relatively numerous, as an integral part of the Albanian people with their distinctive ethnic features that distinguish this element from the Slavic population of the territory of the Republic of Dubrovnik. Despite the value of the archive material of Ragusa and Venice, they have significant limitations in some important directions. At first, their one side character should be taken into account. They are always inclined towards the viewpoint of one or the other state, or in other words, the materials are mainly related to Albanian issue that were in interest of Ragusa, while others were ignored. Consequently, a large portion of materials beyond the relations between Albanians and Venice, or Albanians and Ragusa, where Albanian political and social forces acted as a separate entity, and not as a relational object with Ragusa, are missing. As a result, these sources provide data about the specific geographic locations, as it

17 J. Gelcich, L. Thallóczy, Diplomatarium relationum reipublicae Ragusanae cum regno HungariaeRaguza és Magyarország összeköttetéseinek oklevéltára : a raguzai állami, a bécsi cs. és kir. titkos és egyéb levéltárakban levö okiratokból, Budapest: Magyar Tudományos Akadémia, 1887.

18 Jahja Drançolli, Gjin Gazulli: astronom dhe diplomat i shekullit XV, Rilindja: Prishtina, 1986, passim.

19 SAD, Acta Consilii Minoris, 1415-1472. 
was the Albanian coast, or about the mine sites of Kosovo (their colonies), where their economic interests were focused, or when these attracted their attention. The archives of Albanian rulers, the single first-hand sources that could provide a profound and comprehensive understanding of the principalities in question, have been completely destroyed and disappeared in the anti-Ottoman war wave.

The funds of this archive discovers many Arbanons living in Ragusa (or even in Arbanon regions), who appears in testaments concluded with non-Albanian individuals in Ragusa. Also, there are many cases related to the distribution of testaments of Arbanons (Distributiones Testamentarum). These testaments indicates disputes between Albanians themselves, or between Albanians and the others on various issues (Liber Maleficiorium), lawsuits between Albanians and the others (Sentenitae Cancelariae), bonds or debts between Albanians themselves or with others (Debita Notariea), and trade contracts including Albanians (Diversa Cancellariae).

The trade in goods is undoubtedly the richest subject reflected in the materials of this archive. In addition to coastal cities such as Vlora, Durres, Lezha, Shkodra, Ulcinj, Bar, which were important centers of production and exchange, in the materials of this volume emerge a series of powerful markets in the straits of rivers Shirqi, Shufadaja, Pirgu etc. Albanian export items to the outside world were mainly cereals (frumentum, blada), salt, wood of various types, hides, metals (lead), etc. The materials clearly show that these items came from the interior regions of the country starting from the nearest suburbs of cities to the depths of the country, mainly through local traders who played a key role in domestic trade. In addition to local merchants, in the cities and coastal markets there were also foreign merchants, mainly Venetian and Ragusan, etc. To secure Albanian grain for itself, the Republic of Venice established a monopoly on grain exported from its holdings in Albania, issuing a special order to all its Albanian governors that grain should not be exported elsewhere, but only in Venice. This order, which was rigorously implemented by the Venetian government, has caused serious damages to local merchants, but also to those of Ragusa, as evidenced by its constant complaints, which proves the significance of Albanian grain exports to Ragusa several years ago. To meet her needs for grain and salt, among other articles, Ragusa strengthened trade ties with Vlora and the Pirgu, which became practically its most important and most frequent markets in Albania after the Venetian conquest of coastal cities.

In addition to Albanian exports, imported goods, mainly fabrics, high quality fabrics, luxury items, etc. came to the cities and coastal markets. But we must take into account that the materials we have in the volume reflect only a limited part of all the trade that took place in the Albanian territories, mainly that of the cities that were in Venetian possession or where the Ragusa traders had broken through, i.e. only that part of the trade that had as destination or starting point Venice and Ragusa.

\section{Skanderbeg in Dubrovnik funds}

It should be emphasized that Ragusa maintained a continuous and positive relationship with Skanderbeg. This relation goes back to the age of Skanderbeg's father, Gjon Kastrioti, to whom in F early $1413^{20}$ were granted some trade privileges and the citizenship of Ragusa. Those benefits were 
transferred even to his sons in $1439 .^{21}$

In order to maintain good relations and to support Skanderbeg, Dubrovnik was always very careful and avoided to provoke any enmity with the Ottoman, Venetian or other powers, which at any time could be in conflict with the Arbanon leader. In December 1450, Skanderbeg paid a brief visit to Dubrovnik and on that occasion the government gave him large sums of money in form of gifts. ${ }^{22}$ It is very possible that during this visit Skanderbeg met Gjon Gazulli, with whom he might have been in contact from the past and in 1451 he authorized him for a mission to the Pope in Rome. The Ragusa government benefited from Gazulli's trip to Rome giving him a task to demand from the Pope the release of Ragusa from paying a portion of its liabilities on the occasion of jubilee year 1450-1451. The Ragusans justified this claim not only by their alleged poverty and by permanent Ottoman threat - that was true, but emphasizing their expenses related to "ad aiutar et subvenir el detto Schandarbegh" - "support for Skanderbeg". ${ }^{23}$ The Arbanon humanist and diplomat, Gjon Gazulli, was successful in his efforts: in April 1451, Pope Nicholas V issued a charter allowing the collected indulgences in the territory of Dubrovnik to be divided between Skanderbeg and Dubrovnik. ${ }^{24}$ In this archive, there are also a number of documents that deal with Skanderbeg and his relations with the Pope, Hungary, Venice and Ragusa itself. These documents are mainly found in the various files of the Ragusa Council: Consilii rogatorum, Lettere et Commissioni di Levante, Acta Sanctae Mariae Maioris and less in that of the Consiili Minoris and Consilii Maioris).

The Archives of Vienna "Haus-Hof- und Staatsarchiv" in two events, in 1818 and 1833, took from Dubrovnik almost 200 documents (acts) of Slavic rules of Balkans, but amongst those documents there were also original certificates of Kastriots (Gjon and Gjergj Kastrioti), written in Slavic language. Since they were in Slavic, it was mistakenly thought, and elaborated scientifically as Slavic documents regardless that they indicate to belong to noble Arbanon family of Kastriots. These documents were taken from Dubrovnik Archives by Austria, who at that time was ruling over Dubrovnik. Later, the same material was handed over to Old Yugoslavia after the First World War, but unfortunately they were sent to Royal Academy Archive in Belgrade, and back again to Vienna. The wandering of documents ended after the Second World War, but with many damages caused; particularly, the wax seal of Gjergj Kastrioti was damaged more than that of Gjon Kastrioti.

A majority of these documents, while they were in the State Archives of the Imperial Courtyard in Vienna, during the years 1833-1837, were studied by Slovakian scholar Jozef Pavel Shafarik, ${ }^{25}$ who published a summary of documents, copying the seals of Skanderbeg while still were preserved. The same documents were later studied by A. Iviq. ${ }^{26}$ Description and drawing

21 Alain Ducellier, "La façade maritime de la principauté des Kastriote de la fin du XIVe siècle à la mort de Skanderbeg”, L'Albanie entre Byzance et Venise Xe-XVe siecles, London, 1987, pp.123-125.

22 SAD, Consilii rogatorum, vol.XI, fl.271-272v.

23 SAD, Lettere et Commissioni di Levante, vol.XIV, fl.63'-68.

24 Jovan Radonić, Đurađ Kastriot Skenderbeg i Arbanija u XV veku (istorijska građa), (Spomenik SKA XCV), Beograd: Srpska kraljevska akademija, 1942, no.40; Berisha, Gjergj Kastrioti-Skënderbeu, pp. 226-230.

25 Pavel Josef Šafarík, Monumenta Illyrica Seu Slavorum Gentis Universas Illyrici Sensu sensu latissimo sumti provincias videlicet hodiernam Hungariam, Dalmatiam, Croatiam, Slavoniam, Pragae: typis filiorum Theophili Haase ,1839, p. 29.

26 Aleksa Ivić, Stari srpski pečati i grbovi : prilog srpskoj sfragistici i heraldici, Novi Sad: Izd. Matice Srpske, 1910, pp.9, 12. 
according to a direct look on the great seal of Skanderbeg was made by Tefik Geci in the 60 s of the $\mathrm{XX}$ century. ${ }^{27}$ In the sketches published about the Scanderbeg's seal there are also changes in the shape of the star on the top of the seal, exactly in the circle where the name of the hero is written. According to Dh. Pilikas and T. Geci it is an eight-beam star, whereas according to L. Shllakut, it is an eight-point star.

Exactly, the development of the trade relations with Albania and the stand of the Republic in relation with Scanderbeg, were also defined by this special status that Ragusa had with the great conqueror of the time, the Ottoman Empire. At least, since 1460, the Republic of Saint Blaise faced the complete Ottoman domination in the Balkans. At this time, the Turkish army was coming closer to Ragusa borders. On 1463, the Ottomans defeated the Bosnians, and also killed the last Bosnian king. Two years later, the Ottoman invaders, almost conquered Herzegovina - a territory that has been a special political unit within the kingdom of Bosnia, since the first half of the XV century becoming direct neighbors of the Republic of Ragusa. The Ragusans, as merchants they were, had realized much earlier that this would happened and had established diplomatic relations with the Ottomans. The first official contacts began on 1392, while the Ragusans efforts to negotiate the guarantee for their trade in the Balkans with the Sultan Bayezid I (1389-1402), were crowned on 1396. After that, the contacts continued. The Ragusans intensified their efforts for a modus vivendi ${ }^{28}$ with the Ottomans after the battle of Varna on $1444 .^{29}$

Finally, although some of these funds have been published from time to time by various scholars, to this day there is no systematic publication of them. As far as Albanian scholars are concerned, it remains an obligation and a challenge, not an easy one, but very important, the collection, transcription and transliteration of funds related to the Albanian territories and finally their publication.

\section{Conclusions}

Since its early days, Dubrovnik as a medieval city, a commune, a republic, and as an independent state - payed great attention to the written word and the manner of protecting documents. Some documents are of a great value; the certificates of a particular value were kept in the most holy place - in the city cathedral, among the relics of saints. Currently, the archive repositories stores almost a thousand year old materials - since the beginning of the 11 th century until the present.

The largest number of archive materials, books and documents, particularly from the early period, were written in Latin, which was then the official diplomatic language; but there are lot of documents in Italian and Croatian, Turkish, Serbian etc. The overall structure of the National Archives in Dubrovnik, divided into more than 400 funds and collections, occupies an area of over eight per linear kilometre, and the most precious funds, that of the Dubrovnik Republic, contains

27 Tefik Geci, "Sfragjistika e Kastriotëve", V Convegno internazionele di Studi Albanesi (Atti IX 1968), Palermo,1969, pp.51-68.

28 The Latin expression "modus vivendi" means "way of living", but in this case is used to undermine an agreement or a way that allows the opposite parts to co-live in peace (a kind of compromise).

29 Bariša Krekić, Dubrovnik in the 14th and 15th centuries: A City Between East and West, University of Oklahoma Press, Norman, Oklahoma 1972, p. 58; Bogumil Hrabak, "Dubrovnikasit dhe Gjergj Kastrioti Skënderbeu”, Përparimi, Vjeti XIII, nr.4 (Prishtinë, 1967), p. 446-448. 
over 7,000 bound books and more than 100,000 independent documents, including the manuscripts and printed books of very famous scientists and writers, but also a rich collection of old maps, photographs, postcards, newspapers, magazines and various plans and sketches.

Along with the information that sheds light on the country's economic and political development, these archives, especially the ones of Ragusa, also preserve materials with irreplaceable value on the presence of a relatively large Albanian element; for the city of Kosovo, for mining centres, for Dubrovnik colonies, for their consulates, court disputes etc. There are old documents on Albanians, starting from the trade agreement of 1210 to the Albanian language document as a spoken language in 1284 .

There are many doctrines about the noble Albanian families during the Middle Age: Balsha, Suma, Spani, Muzaka, Kastrioti, etc. It should be noted here that Dubrovnik had positive and continuous relations with our national hero of the XV century, Gjergj Kastriot; this relationship had an early tradition and that was strengthened at the time of his father Gjon Kastrioti, continued even during the epoch of Gjergj Kastrioti - Skanderbeg.

\section{Bibliography:}

Berisha Gjon (2018). Gjergj Kastrioti-Skënderbeu në fondet e Arkivit Shtetëror të Dubrovnikut: dokumente, Prishtinë: Instituti i Historisë“Ali Hadri”.

Čremošnik Gregor (1932). “Kada je postao Dubrovački arhiv?”, Glasnik Zemaljskog muzeja 44, Sarajevo, pp. 57-61.

$\mathrm{SAD}=$ State Archives in Dubrovnik

Dinić Mihailo (1957). Iz dubrovačkog arhiva, I, Beograd: SANU. Prishtina.

Drançolli Jahja (1984). Gjin Gazulli: astronom dhe diplomat $i$ shekullit XV, Rilindja:

Ducellier Alain (1987). "La façade maritime de la principauté des Kastriote de la fin du XIVe siècle à la mort de Skanderbeg", L'Albanie entre Byzance et Venise Xe-XVe siecles, London, pp. 123-125.

Foretić Vinko (1959). "Dubrovački arhiv u srednjem vijeku”, Anali Historijskog instituta JAZU u Dubrovniku 6-7, pp. 315-336.

Geci Tefik (1969). "Sfragjistika e Kastriotëve", V Convegno internazionele di Studi Albanesi (Atti IX 1968), Palermo, pp. 51-68.

Gelčić Josip (1910). "Dubrovački arhiv (Catalogus i.r.Archivii ragusani)", Glasnik Zemaljskog muzeja 22, Sarajevo, pp. 545-589.

Gelcich J., Thallóczy L. (1887). Diplomatarium relationum reipublicae Ragusanae cum regno Hungariae - Raguza és Magyarország összeköttetéseinek oklevéltára, Budapest: Magyar Tudományos Akadémia, 1887.

History of the Republic of Ragusa on paper and parchment: Conservation of Documents and Other Archival Materials from the National Archives in Dubrovnik: 
http://www.h-r-z.hr/images/stories/godina_bastine/dubrovnik_deplijan.pdf 20.10.2020)

Bogumil Hrabak (1967), "Dubrovnikasit dhe Gjergj Kastrioti Skënderbeu”, Përparimi, Vjeti XIII, nr.4 (Prishtinë, 1967).

Ivić Aleksa (1910). Stari srpski pečati i grbovi : prilog srpskoj sfragistici i heraldici, Novi Sad: Izd. Matice Srpske.

Jurić Šime (1962). "Prilozi Biografiji Ivana Gazulića", Anali Historiskog instituta Dubrovnik God. VIII-X, pp. 447-479.

Krekić Bariša (1972). Dubrovnik in the 14th and 15th centuries: A City Between East and West, University of Oklahoma Press, Norman, Oklahoma.

Radonić Jovan (1942). Đurađ Kastriot Skenderbeg i Arbanija u XV veku (istorijska građa), (Spomenik SKA XCV), Beograd: Srpska kraljevska akademija.

Šafařík Pavel Josef (1839). Monumenta Illyrica Seu Slavorum Gentis Universas Illyrici Sensu sensu latissimo sumti provincias videlicet hodiernam Hungariam, Dalmatiam, Croatiam, Slavoniam, Pragae: typis filiorum Theophili Haase.

Shala Teuta (2016). "Prania e etnonimit Albanensis në Raguzë gjatë mesjetës, sipas burimeve dokumentare", Kosova 41, Prishtina, pp. 45-51.

Tadić Jorgo (1964). "Johannes Gazulus, Dubrovnik humanist of the 15th century", Zbornik Filozofskog fakulteta u Beogradu, 8/1, p. 429-454. 